\title{
Atividade peroxidásica em feijoeiro comum (Phaseolus vulgaris L.) cv. Aporé na presença de ácido salicílico e Thanatephorus cucumeris
}

O feijoeiro é cultivado em todas as regiões do país, apresentando grande importância econômica e social, e constitui-se em um dos elementos básicos da alimentação, sendo um dos principais fornecedores de proteínas, ferro e carboidratos. O objetivo deste estudo foi avaliar a indução de proteínas relacionadas à patogênese, de forma específica a enzima peroxidase, em plantas de feijoeiro comum desafiadas com indutores bióticos e abióticos. Para isso, foi borrifado $1 \mathrm{~mL}$ de solução de ácido salicílico (AS) $10 \mathrm{mM}$ nas folhas primárias de feijoeiro, e posteriormente estas foram coletadas em quatro tempos: $0,24,48$ e 72 hai (horas após a inoculação) e armazenadas em freezer -20 C para realização das análises bioquímicas. A cultivar apresentou teores de proteínas variando de 0,046 a 0,076 $\mathrm{mgP} / \mathrm{mL}$ nas plantas testadas com água e inoculadas com o fungo, apresentando pico de proteína 72 hai. Nas plantas testadas com ácido salicílico $10 \mathrm{mM}$ e posteriormente inoculadas com o fungo, os valores variaram de 0,052 a $0,086 \mathrm{mgP} / \mathrm{mL}$, com pico de proteína 24 hai. Os níveis de atividade peroxidásica (POX) variaram de 5,31 a 29,37 UA/mgP nas plantas inoculadas com água e fungo e de 1,17 a 22,83 UA/mgP nas plantas tratadas com ácido salicílico e o fungo. As plantas tratadas com o AS $10 \mathrm{mM}$ e depois inoculadas com o fungo mostraram pico de atividade POX 24 horas após a inoculação do patógeno, enquanto que nas plantas tratadas com água o pico de atividade POX ocorreu 72 horas após a inoculação do patógeno. Os resultados alcançados até o momento sugerem um potencial do ácido salicílico como indutor da resposta de defesa do feijoeiro comum contra o fungo T. cucumeris.

Palavras-chave: Feijão; Indução de Resistência; T. cucumeris.

\section{Peroxidase activity in common bean (Phaseolus vulgaris L.) cv. Aporé in the presence of salicylic acid and Thanatephorus cucumeris}

\begin{abstract}
The bean is grown in all regions of the country, presenting great economic and social importance, and constitutes one of the basic elements of food, being one of the main suppliers of proteins, iron and carbohydrates. The aim of this study was to evaluate the induction of pathogenesis-related proteins, specifically the peroxidase enzyme, in common bean plants challenged with biotic and abiotic inducers. For this, $1 \mathrm{~mL}$ of $10 \mathrm{mM}$ salicylic acid (AS) solution was sprayed on the primary leaves of beans, and later these were collected in four stages: 0, 24, 48 and 72 hai (hours after inoculation) and stored in a freezer -20 ${ }^{\circ} \mathrm{C}$ for biochemical analysis. The cultivar showed protein contents ranging from 0.046 to $0.076 \mathrm{mgP} / \mathrm{mL}$ in the plants tested with water and inoculated with the fungus, showing a peak protein of 72 hai. In plants tested with $10 \mathrm{mM}$ salicylic acid and subsequently inoculated with the fungus, the values ??ranged from 0.052 to $0.086 \mathrm{mgP} / \mathrm{mL}$, with a 24 ha protein peak. The levels of peroxidase activity (POX) ranged from 5.31 to $29.37 \mathrm{AU} / \mathrm{mgP}$ in plants inoculated with water and fungus and from 1.17 to $22.83 \mathrm{AU} / \mathrm{mgP}$ in plants treated with salicylic acid and the fungus. Plants treated with $10 \mathrm{mM}$ AS and then inoculated with the fungus showed peak POX activity 24 hours after inoculation of the pathogen, while in plants treated with water, peak POX activity occurred 72 hours after inoculation of the pathogen. The results achieved so far suggest a potential for salicylic acid to induce the defense response of common beans against the fungus T. cucumeris.
\end{abstract}

Keywords: Bean; Resistance Induction; T. cucumeris.

Topic: Proteção de Plantas e Fitotecnia

Reviewed anonymously in the process of blind peer
Received: 06/12/2019

Approved: $12 / 01 / 2020$
Cleberson de Freitas Fernandes (iD) Embrapa Agroindústria Tropical, Brasil http://lattes.cnpq.br/7426209328649448 http://orcid.org/0000-0001-5269-1139 cleberson.fernandes@embrapa.br

José Roberto Vieira Junior (iD Embrapa Rondônia, Brasil http://lattes.cnpq.br/9904275274067824 http://orcid.org/0000-0001-7939-8119 jose-roberto.vieira@embrapa.br

Pollyana das Neves de Aguiar Faculdades Integradas Aparício Carvalho, Brasil http://lattes.cnpq.br/7046692705346760 pollyaninhaaguiar@hotmail.com

Mayara França de Souza
Faculdades Integradas Aparício Carvalho, Brasil
http://lattes.cnpq.br/4387167473777724
$\underline{\text { bruxinhamay@hotmail.com }}$
Tamiris Chaves Freire@
Universidade Federal de Rondônia, Brasil
http://lattes.cnpq.br/4372408393666360
http://orcid.org/0000-0002-8938-3751
tamirischavesfreire@gmail.com
Aline Souza da Fonseca (1D
Universidade Federal de Rondônia, Brasil
http://lattes.cnpq.br/0456233723446786
http://orcid.org/0000-0002-4019-3412
alinesouzadafonseca@gmail.com

Rita de Cássia Alves Universidade Federal de Rondônia, Brasil http://lattes.cnpq.br/6159264388864891 rita diggory@hotmail.com
Referencing this:

FERNANDES, C. F.; VIEIRA JUNIOR, J. R.; AGUIAR, P. N.; SOUZA, M. F.; FREIRE, T. C.; FONSECA, A. S.; ALVES, R. C.. Atividade peroxidásica em feijoeiro comum (Phaseolus vulgaris L.) cv. Aporé na presença de ácido salicílico e Thanatephorus cucumeris. Revista Ibero Americana de Ciências Ambientais, v.11, n.1, p.72-79, 2020. DOI: http://doi.org/10.6008/CBPC2179-6858.2020.001.0008 


\section{INTRODUÇÃO}

O feijoeiro comum (Phaseolus vulgaris L.) é uma das principais culturas produzidas, sendo um dos principais alimentos consumidos no Brasil e no mundo, componente básico na dieta alimentar de diversas populações (BARBOSA et al., 2012). Essa cultura é encontrada em vários sistemas produtivos brasileiro, desde a agricultura familiar, pequeno produtor, até agricultura especializada empresarial (BRITO et al., 2015).

Boa parte da necessidade proteica da população é suprida pelos grãos (ABBASI et al., 2015). O feijoeiro comum encontra-se como uma leguminosa relevante na alimentação, isso se deve ao fato de ser uma fonte de proteína de fácil acesso. Tem distribuição ampla em todo o Brasil, sendo importante aos pequenos produtores por ser uma alternativa de cultivo agrícola (GONÇALVES et al., 2015), com um consumo nacional variando entre 3,3 e 3,6 milhões de toneladas, em razão da disponibilidade interna e dos preços praticados no mercado que induzem o consumidor a adquirir mais ou menos produtos (CONAB, 2015).

Estima-se que a área total de feijão poderá ser menor em 8,1\%, em comparação com a safra passada. A produção nacional deverá ficar 5,2\% menor que a última temporada (CONAB, 2015). A cultura pode ter sua taxa de produtividade aumentada, necessitando para isto ampliar o uso de tecnologias, como por exemplo, usar um manejo adequado da adubação e da irrigação (OLIVEIRA, 2015).

Outro ponto importante na redução desta produção é a ocorrência de doenças, entre as quais se destaca a mela do feijoeiro, doença causada pelo fungo Thanatephorus cucumeris (anamorfo Rhizoctonia solani Kühn), uma das principais doenças na região amazônica com perdas elevadas e, em alguns casos, levando a perdas totais.

As plantas apresentam, de maneira geral, um eficiente mecanismo de defesa frente ao ataque de microrganismos. Este processo de defesa se inicia desde o momento da interação entre o patógeno e o hospedeiro, o qual desencadeia uma cascata de processos e sinais, que são responsáveis pela ativação de diferentes agentes de defesa. Entre estes agentes se destacam as proteínas relacionadas a patogênese e as espécies reativas de oxigênio, que são fundamentais na resposta contra o patógeno, assim que o mesmo entra em contato com a planta (VAN LOON, 1997).

As defesas utilizadas pelas plantas são diversas, como resposta hipersensitiva (HR), resistência sistêmica adquirida (SAR), resistência sistêmica induzida (ISR), indução de proteínas relacionadas à patogênese (PR-proteínas) e compostos sinalizadores como ácido salicílico (AS), óxido nítrico e peróxido de hidrogênio (AGRIOS, 2004).

A resposta sistêmica adquirida protege partes da planta que não foram atacadas e o processo que conduz essa indução tem início na expressão de genes codificadores que podem ser ativados pelos elicitores aplicados nas plantas (BORSATTI et al., 2015). Acredita-se que a resistência sistêmica se inicia no momento da interação planta - patógeno levando a alterações no seu metabolismo celular que levariam a emissão de sinais moleculares dirigidos para outras partes da planta (HAMMERSCHMIDT, 2007).

As resistências sistêmicas se apresentam de duas formas, resistência sistêmica adquirida e resistência sistêmica induzida. A resistência sistêmica adquirida (SAR) está ligada ao aumento do ácido salicílico e à 
expressão de proteínas relacionadas à patogenicidade (PR-proteínas), sendo provocada por estresses bióticos e abióticos. Em relação à resistência sistêmica induzida (ISR) esta é desencadeada pela ação do gás etileno e do ácido jasmônico e é induzida pela própria planta (HAMMOND-KOSACK et al., 1996; WALLING, 2001).

O Ácido salicílico é um hormônio vegetal sintetizado pela via fenilpropanoide, sendo assim um composto de origem fenólica, com funções de regulação no metabolismo. $\mathrm{O}$ ácido salicílico age a nível celular como um dos sinalizadores para o início do processo de defesa, juntamente com jasmonatos e etileno. Uma das funções é sinalizar para as outras partes da planta, pelo floema, na forma de metilsalicilato, que seja ativado a defesa, pois a mesma está sendo atacada (KUNKEL et al., 2002; ABBASI et al., 2014; MAZZUCHELLI et al., 2014; BORSATTI et al., 2015).

O Acibenzolar-S-Metil, junto com ácido jasmônico, e o etefon induzem significativamente o início do aumento da resistência da planta frente ao fitopatógeno, onde componentes letais aos mesmos como fitoalexinas são produzidas a partir de proteínas codificadas na ativação dos genes da interação plantapatógeno (LAMB et al., 1997). O objetivo deste estudo foi avaliar a indução da peroxidase em plantas de feijoeiro comum desafiadas com indutores bióticos e abióticos.

\section{MATERIAIS E MÉTODOS}

Material Vegetal e Desenho Experimental: Para o presente estudo sementes de feijão tipo Carioca variedade Aporé foram utilizadas. $O$ experimento foi conduzido em casa de vegetação da Embrapa Rondônia. O plantio das sementes foi realizado em copos plásticos com capacidade de $300 \mathrm{~mL}$ contendo solo, onde foram plantadas duas sementes de feijão por copo. Estes foram mantidos em casa de vegetação, sob irrigação diária, e após 16 dias as folhas primarias das plântulas foram pinceladas com água destilada estéril (controle) e com uma solução de ácido salicílico 10 mM (tratada). Os dois grupos foram, 24 horas após o tratamento, inoculadas com a suspensão de esporos do fungo T. cucumeirs $\left(1,2 \times 10^{4}\right.$ esporos $\left./ \mathrm{mL}\right)$, tendo sido aplicado 1 $\mathrm{mL}$ da solução de esporos na face adaxial das folhas.

Após $0,24,48$ e 72 horas após a inoculação (hai), as folhas inoculadas foram coletadas, lavadas com água grau Milli-Q, secas em papel filtro, pesadas e mantidas a $-20 \stackrel{\circ}{ }$ C. Estas folhas foram utilizadas para os ensaios de determinação de proteínas e análises enzimáticas. 0 delineamento experimental utilizado foi o inteiramente casualizado, com três repetições. A comparação entre as médias foi feita por meio do desvio padrão da média ao longo do tempo. Cada média foi resultado de determinação em triplicata para cada um dos parâmetros estudados.

Preparação do Extrato Total: Para a obtenção do extrato total, as amostras foram maceradas em nitrogênio líquido, até obtenção de um fino pó. O procedimento foi realizado em banho de gelo, e o material

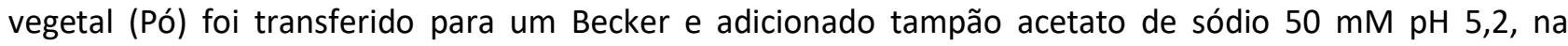
proporção de 1:5 (p/v). O material permaneceu em agitação $(100 \mathrm{rpm})$ durante 10 minutos. O extrato foi filtrado em pano de nylon de trama fina e centrifugado $\left(15^{\prime}, 4^{\circ} \mathrm{C}, 13.000 \mathrm{rpm}\right)$. O sobrenadante foi coletado e armazenado em tubos de ensaio e acondicionado em freezer a -20 ㄷ para posteriores análises enzimáticas. 
Determinação de Proteínas Totais: Para determinação dos teores de proteínas se utilizou a metodologia descrita por Bradford, com alíquotas de $100 \mu \mathrm{L}$ do extrato total onde estas foram acrescidas de $2500 \mu \mathrm{L}$ do reagente de Bradford. A mistura foi agitada (vortex) por cinco segundos e permaneceu em repouso por um período de 10 minutos em temperatura ambiente, logo após, foi realizada a leitura em espectrofotômetro Femto 700plus no comprimento de onda de $595 \mathrm{~nm}$. O teor de proteínas solúveis foi calculado utilizando uma curva padrão construída a partir de concentrações conhecidas de albumina sérica bovina (BSA).

Determinação da Atividade Peroxidásica: A atividade da enzima peroxidase foi quantificada de acordo com a metodologia descrita por Urbanek e colaboradores. Como substratos da reação foram utilizados o guaiacol, doador de prótons e o peróxido de hidrogênio, receptor. A peroxidase catalisa a reação, produzindo um composto colorido, 3,3'-dimetroxi-4-4'-bifenolquinona, que é medido por espectrofotometria na região do visível. Alíquotas de $0,02 \mathrm{~mL}$ de extrato das folhas foram adicionadas a uma solução contendo $1,98 \mathrm{~mL}$ de tampão acetato de sódio $50 \mathrm{mM}, \mathrm{pH} \mathrm{5,2,1,0} \mathrm{mL} \mathrm{de} \mathrm{peróxido} \mathrm{de} \mathrm{hidrogênio}$ $0,06 \mathrm{M} \mathrm{e} 1 \mathrm{~mL}$ de guaiacol 0,02 M, perfazendo o volume total de $4 \mathrm{~mL}$. A mistura foi deixada em banho-maria a $30^{\circ} \mathrm{C}$, durante 10 minutos. Em seguida, foi feita a leitura da absorbância no comprimento de onda a 480 nanômetros em espectrofotômetro FEMTO 700 Plus. A variação de uma unidade de absorbância por minuto foi assumida como sendo uma unidade de atividade peroxidásica (UAP).

\section{RESULTADOS E DISCUSSÃO}

Os teores de proteínas dos extratos das plantas avaliadas não mostraram, de maneira geral, grandes variações nos tratamentos avaliados, com exceção dos tempos 24 e 48 hai, onde um aumento nos teores de proteínas foi observado nas plantas que foram tratadas com o ácido salicílico $10 \mathrm{mM}$ (Figura 1).

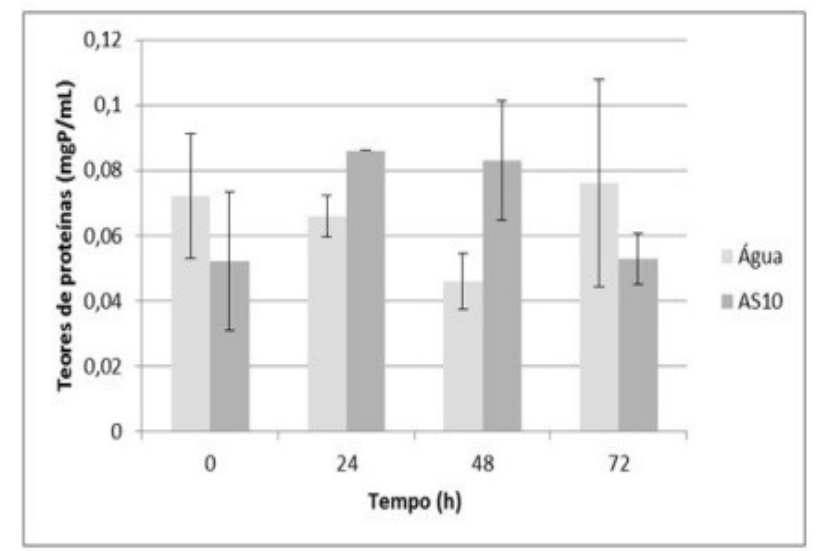

Figura 1: Teores de proteínas em extratos totais de feijoeiro na presença e ausência de ácido salicílico $10 \mathrm{mM}$ e inoculado com o fungo Thanatephorus cucumeris.

A cultivar Aporé apresentou teores de proteínas variando de 0,046 a 0,076 mgP/mL nas plantas testadas com água e inoculadas com o fungo, apresentando pico de proteínas 72 hai. Nas plantas testadas com o ácido salicílico $10 \mathrm{mM}$ e posteriormente inoculadas com o fungo, os valores variam de 0,052 a 0,086 $\mathrm{mgP} / \mathrm{mL}$, com pico de proteína 24 hai. 
A atividade peroxidásica apresentou resposta diferenciada nos extratos de folhas primárias de feijoeiro comum, cultivar Aporé, nos tratamentos avaliados. Nos extratos de folhas tratadas com água e em seguida inoculada com a suspensão esporos do fungo, a atividade peroxidásica variou de 5,31 a 29,37 UA/mgP, alcançando pico máximo 72 hai. Para os extratos de folhas previamente tratadas com ácido salicílico $10 \mathrm{mM}$ e posteriormente inoculadas com a suspensão de esporos a atividade peroxidásica mostrou níveis que variam de 1,17 a $22,83 \mathrm{UA} / \mathrm{mgP}$ (Figura 2).

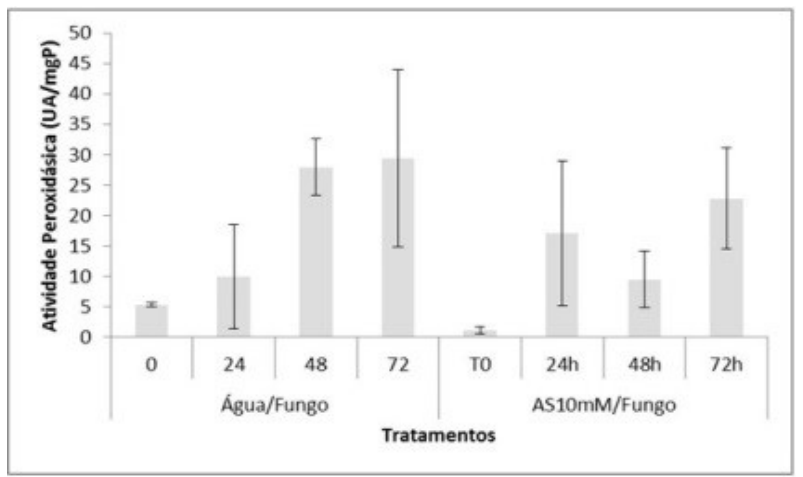

Figura 2: Atividade peroxidásica em extratos de folhas primárias de feijoeiro comum, cv. Aporé, na presença e ausência de ácido salicílico $10 \mathrm{mM}$ e inoculadas com o fungo Thanatephorus cucumeris.

Os resultados obtidos no presente estudo mostraram, para o tratamento água/fungo, um aumento significativo da atividade peroxidásica ao longo do tempo, tendo os níveis de atividade aumentado em 5,5 vezes quando comparado com o tempo inicial (TO). Este aumento pode ser explicado pela resposta de defesa da planta ao ataque do patógeno, lançando mão de seu arsenal bioquímico de defesa para tentar impedir e/ou retardar a penetração do fungo.

Para os tratamentos Ácido Salicílico (AS) 10 mM/fungo, a resposta da atividade peroxidásica mostrou resposta diferenciada, com picos de atividade em 24 e 72 hai. Este aumento da atividade foi de cerca de 19,5 vezes quando comparado com o tempo inicial (T0). Pode-se também observar que a resposta neste tratamento para o tempo 24 horas foi maior do que para o tratamento água/fungo, o sugere que o tratamento com ácido salicílico pode ter contribuído para uma maior eficácia nesta resposta nos tempos iniciais de ataque do fungo. Os dados da atividade peroxidásica são representados na Tabela 2.

Tabela 2: Atividade peroxidásica (POX) em extratos totais de folhas primárias de feijoeiro comum, cultivar Aporé, na presença e ausência de ácido salicílico $10 \mathrm{mM}$ e inoculado com o fungo $R$. solani

\begin{tabular}{|l|l|l|}
\hline Tempo & $\begin{array}{l}\text { Atividade POX (UA/mgP) água + Rhizoctonia } \\
\text { solani }\end{array}$ & $\begin{array}{l}\text { Atividade POX (UA/mgP) AS mM + Rhizoctonia } \\
\text { solani }\end{array}$ \\
\hline Oh & 5,31 & 1,17 \\
$24 \mathrm{~h}$ & 9,95 & 17,07 \\
$48 \mathrm{~h}$ & 27,98 & 9,50 \\
$72 \mathrm{~h}$ & 29,37 & 22,83 \\
\hline
\end{tabular}

Mazzuchelli et al. (2014), verificou que a aplicação de ácido salicílico nas concentrações de $100 \mathrm{mM}$, $200 \mathrm{mM}$ e $300 \mathrm{mM}$ reverteu limitação estomática em plantas de eucalipto submetidas a deficiência hídrica, indicando a manutenção da fotossíntese. Além disso, foi observado que as plantas com a aplicação de ácido salicílico aumentaram de tamanho em todas as concentrações, porem em 300 mg L-1 houve ainda um 
amento da área foliar.

O ácido salicílico pode aumentar a atividade antioxidante de folhas, como citou Rodrigues-Brandão et al. (2014) com A. tenella, que teve sua atividade aumentada depois da adição de ácido salicílico, induzindo também na síntese de betacianina. No trabalho de Coltro et al. (2013) o tratamento de morangos com ácido salicílico e choque térmico, após 14 se observou um aumento do teor de compostos fenólicos, que aparenta se relacionar com os mecanismos de defesa da fruta frente a expressão de enzimas do metabolismo oxidativo. Porém, $\mathrm{O}$ tratamento de sementes com ácido salicílico não influenciou a qualidade de sementes do arroz em várias concentrações (TAVARES et al., 2012).

Plantas de trigo foram tratadas com ácido salicílico $(0,1 \mathrm{~mm})$ e paclobutrazol $(5 \mathrm{mg}-1)$, entre os objetos analisado, enzimas. Para os tratamentos houve um aumento na atividade enzimática de atividades antioxidantes que reduz o H2O2 e peroxidação lipídica. As atividades com ácido salicílico foram relevantes, porem menores quando comparado ao tratamento com Paclobutrazol (ABBASI et al., 2015).

Em outro trabalho, usou-se o ácido salicílico para embeber sementes de feijão cv. IAC-Carioca expostos anteriormente a choque frio $\left(S-7^{\circ} \mathrm{C} 24 \mathrm{~h}-1\right)$ e ácido salicílico (SA - 48h de $\left.0,01 \mathrm{mM}-1\right)$ usando água como testemunha. Após as sementes foram tratadas com manitol $(0,-0.3,-0.6$ e -1.2 MPa) e avaliadas na fase de germinação (sete dias após o início da germinação) e notou-se que na avaliação eletroforética de proteínas e se notou que o ácido salicílico influenciou no padrão de proteínas das sementes, mostrando ser promissor para a tecnologia de tratamento de sementes, tendo em vista o resultado benéfico das plantas no teste final comparadas à testemunha (AGOSTINI et al., 2013).

Mudas de Gloxínia (Sinningia speciosa Benth.) foram tratadas com ácido salicílico em concentrações de 1,0 a 0,0001 $\mu \mathrm{M}$ para testar o feito dele na floração das plantas, onde foi feito a pulverização sobre os brotos em três tempos diferentes. Os resultados mostraram as plantas tratadas com ácido salicílico, obteve um aumento de 25 a 37\% do número total de flores em relação ao controle, aumento na área total da flor e florescimento mais prematuro, mesmo na menor concentração testada. Pode ser que a aplicação de ácido salicílico acelerou o início da floração estimulada por uma maior absorção de nutrientes por ter havido uma expressão proteica importante para a indução do florescimento.

Edagi et al. (2011), imergiu amostra de frutos de Fukuhara em água destilada durante 5 min, outras amostras em solução a 1 ou $10 \mathrm{mmol} \mathrm{L}^{-1}$ de ácido salicílico durante 5 min e outras amostras foram expostas a $0,05 \mathrm{mmol} \mathrm{L}^{-1}$ de metil salicilato por 16 horas. Onde observaram que os frutos tratados com ácido salicílico apresentaram redução de escurecimento no interior do fruto por até 45 dias em uma temperatura de $1^{\circ} \mathrm{C}$, mas o resultado mais satisfatório para comercialização foram os frutos tratados com metil salicilato. Observou ainda que os frutos tratados com $0,05 \mathrm{mmol} \mathrm{L}^{-1}$ de metil salicilato obteve uma atividade baixa da peroxidase e polifenoloxidase ao final do armazenamento.

\section{CONCLUSÕES}

Os resultados sugerem uma participação importante da enzima POX no mecanismo de defesa do feijoeiro comum contra o ataque do fungo T. cucumeris. No entanto, os níveis maiores de atividade POX no 
tratamento com ácido salicílico $10 \mathrm{mM}$ sugerem que este composto pode desempenhar um papel importante na resposta iniciais do feijoeiro ao fungo, atuando na ativação do mecanismo de defesa como, por exemplo, em enzimas que atuem no processo de lignificação da parede celular, como a peroxidase.

Para as análises realizadas na variedade Aporé, os resultados alcançados até o momento sugerem o potencial do ácido salicílico como indutor da resposta de defesa do feijoeiro comum contra o fungo Thanatephorus cucumeris. Esta participação deve envolver ainda as enzimas relacionadas ao estresse oxidativo da planta, notadamente catalase, ascorbato peroxidase, bem como PR-Proteínas e outros compostos.

AGRADECIMENTOS: ao Conselho Nacional de Desenvolvimento Científico e Tecnológico (CNPq), Financiadora de Estudos e Projetos (FINEP), Fundação Rondônia de Amparo ao Desenvolvimento das Ações Científicas e Tecnológicas e de Pesquisa do Estado de Rondônia (FAPERO). Ao Domingos Sávio G. Silva (in memoriam) e ao Antônio M. Marques pela assistência técnica.

\section{REFERÊNCIAS}

ABBASI, A.; SHEKARI, F.; MUSTAFAVI, S. H.. Effect of paclobutrazol and salicylic acid on antioxidants enzyme activity in drought stress in wheat. Idesia (Arica), v.33, n.4, p.5-13, 2015. DOI: http://dx.doi.org/10.4067/S0718$\underline{34292015000400002}$

AGOSTINI, E. A. T.; MACHADO-NETO, N. B.; CUSTODIO, C. C. Induction of water deficit tolerance by cold shock and salicylic acid during germination in the common bean. Acta Scientiarum. Agronomy, v.35, n.2, p.209-219, 2013. DOI: http://dx.doi.org/10.4025/actasciagron.v35i2.15967

AGRIOS, G. N.. Plant Pathology. 5 ed. San Diego: Elsevier Academic Press, 2004.

BARBOSA, F. R.; GONZAGA, A. C. D. O.. Informações técnicas para o cultivo do feijoeiro comum na Região CentralBrasileira: 2012-2014. Santo Antônio de Goiás: Embrapa Arroz e Feijão, 2012.

BORSATTI, F. C.; MAZARO, S. M.; DANNER, M. A.; NAVA, G. A.; DALACOSTA, N. L.. Indução de resistência e qualidade pós-colheita de amora-preta tratada com ácido salicílico. Rev. Bras. Frutic., Jaboticabal, v.37, n.2, p.318-326, 2015. DOI: http://dx.doi.org/10.1590/0100-2945-087/14

BRITO, L. F.; PACHECO, R. S.; FILHO, B. F. S.; FERREIRA, E. P. B.; STRALIOTTO, R.; ARAÚJO, A. P.. Resposta do Feijoeiro Comum à Inoculação com Rizóbio e Suplementação com Nitrogênio Mineral em Dois Biomas Brasileiros. Revista Brasileira de Ciência do Solo, v.39, n.4, p.981-992, 2015. DOI: http://dx.doi.org/10.1590/01000683rbcs20140322

COLTRO, S.; BROETTO, L.; ROTILLI, M. C. C.; MORAES, A. J.; BARP, F. K.; BRAGA, G. C.. Heat shock and salicylic acid on postharvest preservation of organic strawberries Rev. Ceres, Viçosa, v.61, n.3, p.306-312, 2014. DOI: http://dx.doi.org/10.1590/S0034-737X2014000300002

CONAB. Companhia Nacional de Abastecimento.
Acompanhamento da Safra Brasileira - Grãos, v.2 - Safra 2014/15, n.9. 2015.

EDAGI, F. K.; SESTARI, I.; SASAKI, F. F.; TERRA, F. A. M.; KLUGE, R. A.. Compostos salicilados e tolerância de nêsperas ao frio. Pesquisa agropecuária brasileira, v.46, n.5, 2011. DOI: http://dx.doi.org/10.1590/S0100-204X2011000500015

GONÇALVES, L. D.; BARELLI, M. A. A.; SANTOS, P. R. J.; CARVALHO, T. C.; SILVA, C. R.; NEVES, L. G.; POLETINE, J. P.; LUZ, P. B.. Variabilidade genética de germoplasma tradicional de feijoeiro comum na região de Cáceres-MT. Ciência Rural, v.46, n.1, 2016. DOI: http://dx.doi.org/10.1590/0103-8478cr20140812

HAMMERSCHMIDT, R.. Introduction: definitions and some history. In: WALTERS, D.; NEWTON, A.; LYON, G.. Induced Resistance for Plant Defense: A Sustainable Approach to Crop Protection. East Lansing: Blackwell Publishing, 2007. p.1-8.

HAMMOND-KOSACK, K.; JONES, J. D. G.. Resistance genedependent plant defense responses. Plant Cell, Rockville, v.8, p.1773-1791, 1996. DOI: http://dx.doi.org/10.1105/tpc.8.10.1773

KUNKEL, B. N.; BROOKS, D. M.. Cross talk between signaling pathways in pathogen defense Current Opinion in Plant Biology, v.5, n.2, p.325-331, 2002. DOI: http://dx.doi.org/10.1016/S1369-5266(02)00275-3

LAMB, C.; DIXON, R. A.. The oxidative burst in plant disease. Annual Review of Plant Physiology, v.48, p.251-275, 1997. DOI: http://dx.doi.org/10.1146/annurev.arplant.48.1.251

MAZZUCHELLI, E. H. L.; MAZZUCHELLI, E. H. L.; SOUZA, G. M.; A.. C. P.. Rustificação de mudas de eucalipto via aplicação de ácido salićlico. Pesqui. Agropecu. Trop., v.44, n.4, 2014. DOI: http://dx.doi.org/10.1590/S1983-40632014000400012 
OLIVEIRA, F. A.; MEDEIROS, J. F.; ALVES, R. C.; LIMA, L. A.; SANTOS, S. T.; REGIS, L. R.. Produção de feijão caupi em função da salinidade e regulador de crescimento. Campina Grande, PB. 2015. Revista Brasileira de Engenharia Agrícola e Ambiental, v.19, n.11, p.1049-1056, 2015. DOI:

http://dx.doi.org/10.1590/18071929/agriambi.v19n11p1049-1056

RODRIGUES-BRANDÃO, I.; KLEINOWSKI, A. M.; EINHARDT, A. M.; LIMA, M. C.; AMARANTE, L.; PETERS, J. A.; BRAGA, E. J. B.. Salicylic acid on antioxidant activity and betacyan in production from leaves of Alternanthera tenella. Ciência Rural, Santa Maria, v.44, n.10, p.1893-1898, 2014. DOI: http://dx.doi.org/10.1590/0103-8478cr20130873
TAVARES, L. C.; RUFINO, C. A.; OLIVEIRA, S.; BRUNES, A. P.; VILLELA, F. A.. Treatment of rice seeds with salicylic acid: seed physiological quality and yield. Journal of Seed Science, v.36, n.3, p.352-356, 2014. DOI: http://dx.doi.org/10.1590/2317-1545v36n3636

VAN LOON, L. C.. Induced resistance in plants and the role of pathogenesis-related proteins. European Journal of Plant Pathology, v.103, p.753-765, 1997. DOI: http://dx.doi.org/10.1023/A:1008638109140

WALLING, L. L.. Induced resistance: from the basic to the applies. Trends in Plant Science, v.6, n.10, p.455-447, 2001. DOI: http://dx.doi.org/10.1016/s1360-1385(01)02046-5

A CBPC - Companhia Brasileira de Produção Científica (CNPJ: 11.221.422/0001-03) detém os direitos materiais desta publicação. Os direitos referem-se à publicação do trabalho em qualquer parte do mundo, incluindo os direitos às renovações, expansões e disseminações da contribuição, bem como outros direitos subsidiários. Todos os trabalhos publicados eletronicamente poderão posteriormente ser publicados em coletâneas impressas sob coordenação da Sustenere Publishing, da Companhia Brasileira de Produção Científica e seus parceiros autorizados. Os (as) autores (as) preservam os direitos autorais, mas não têm permissão para a publicação da contribuição em outro meio, impresso ou digital, em português ou em tradução. 